\title{
EMPLOYMENT IN HUNGARIAN ECONOMY AS A RESULT OF THE COVID-19 PANDEMIC
}

\author{
Arnold TÓTH \\ Department of Business Economics, Faculty of Finance and Accountancy, Budapest \\ Business School, Hungary \\ Botond KÁLMÁN
}

Doctoral School of Economic and Regional Sciences, Hungarian University of Agriculture and Life Sciences, Budapest, Hungary

\section{József POÓR}

Department of Management, Faculty of Economics and Informatics, J. Selye University, Komárno, Slovakia

Received: 06. April 2021, Reviewed: 27. May 2021, Accepted: 15. June 2021

\begin{abstract}
By the summer of 2020, the COVID-19 epidemic that originated from China became a global pandemic. The restrictive measures that were put in place for protection also affected the economy, which during the first wave of the pandemic came to a halt in almost every country. This paper examines the effect of the pandemic on Hungarian employment rates based on data by Eurostat, in different sectors of the economy and by using the EU-27 average as reference. In addition to complete employment data, we also focused on employees and those who are self-employed. To measure the effects of COVID-19, we contrasted data from the previous three years to data from the first and second quarter of 2020. Our results confirm that the pandemic caused a significant decrease in general employment indexes but did not equally affect the various branches of the economy.
\end{abstract}

Keywords: economy, employment, employee, self-employment, COVID-19

JEL Classification: $\mathrm{H} 12, \mathrm{~J} 81, \mathrm{~J} 21$

\section{Introduction}

In Hungary, the first phase of the national research project, from which the first research report was published on 1 October 2020, took place from May to August 2020 (Poór \& al., 2020; Balogh et al., 2020). The aim of the study was to assess the impact of the COVID-19 pandemic on the Hungarian corporate and institutional sector 
and to develop proposals for dealing with and solving the problems, primarily from the perspective of human resource management (HRM). In addition to 11 Hungarian universities, J. Selye University of Komárno, as well as regional chambers and training centres also participated in the research. With their online questionnaire, they collected and analysed data from 500 Hungarian organizations using a broad statistical methodology. Currently, the research is in the second phase, which examines the issue not only in Hungary but also in the neighbouring countries with a questionnaire survey adapted to the given national linguistic and economic specifics. The publication of partial results in journals belonging to the field has also started (Balogh et al., 2020). This large-scale work prompted the authors of the present work to write the following study.

\section{Theoretical background}

Human capital is one of the most inalienable assets that an individual can possess and bind to the individual as long as he or she is healthy. Contrary to all misconceptions (Chulanova, 2017), some elements of the aforementioned recognition can be found even in early economic theories (Smith, 1776). Later, as a truly integrative theory, it appeared at the Chicago School (Schultz, 1968). .In this sense, human capital is fundamental to economic growth (Kiseláková et al., 2018). This statement was grounded in the work of two Nobel Prize-winning scientists, Schultz (Schultz, 1961) and (Schulz, 1980) and Fogel (Fogel, 1994), as early as the second half of the 1900s, but it became particularly relevant during the Industry 4.0 period. $10-30$ percent of the differences in gross domestic product (GDP) per capita across countries can be attributed to human capital (Hsieh \& Klenow, 2010). COVID-19 is a threat to this valuable asset (Carnevale \& Hatak, 2020; Caligiuri et al., 2020). Wide access to education and health is a prerequisite for creating the high-quality human capital (Douglass, 2010; Ezzul Esa et al., 2019; Pasban \& Nojedeh, 2016) required by today's labour market; and this fact highlights the role of governments in crisis management (Dzhurova, 2020; Adeel et al., 2020; Szellö, 2020). States are ranked by the World Economic Forum (WEF) Human Capital Index (HCI) on the basis of education and training, appropriate skills, and labour market performance (Samans et al., 2017). Of the 130 countries surveyed, Hungary ranked 39th in the most recently published report. WEF determines human capital quality with a four-dimensional composite index, namely: capacity, deployment, development, and know-how. However, scientific literature analyses human capital based on the definition of the World Bank, and measures and forecasts in three fields: knowledge, skills, and health (World Bank, 2020). While the roll of knowledge and skills was accentuated previously, COVID-19 pointed out that not even health is negligible - nevertheless, also Fogel emphasised the role of health status in economic prosperity in his Nobel Prize-winning study. Knowledge-skills-health dimensions are useful for measuring and prediction. Notwithstanding, we only draw attention to the significance of human capital in this paper, but we found our evaluations and predictions on employment data and their changes.

Based on the labour market data of the Hungarian Central Statistical Office (KSH, 2020), the domestic labour market indicators have shown an improving trend in recent years, and economic activity and employment have been growing steadily since 2011. The number of employees in the last quarter of 2019 was 4 million 520 thousand, and the employment rate reached 70 percent. This represents a 15-percentage-point increase over 10 years. In 2019, the number of people in public employment decreased, while the number of people working in the primary labour market increased. Also, more people worked abroad than in the previous year. Due to the tight labour market, 
the bargaining power of workers and employees has improved (Bakó \& Lakatos,2020). The coronavirus epidemic significantly worsened economic expectations and macroeconomic forecasts for the coming years (Szappanos, 2020). In April 2020, the Hungarian economic sentiment index fell significantly (GKI, 2020a), within which the business confidence index fell by about 25 percentage points and that of consumers by almost 40 percentage points. Within the business sector, expectations of services deteriorated the most, while those of industry deteriorated the least. The proportion of companies expecting production cuts has more than tripled in one month. The positive employment propensity of recent years has fallen into the negative range, mostly in industry, i.e., most companies have been thinking about redundancies rather than recruitment and expansion. As early as April, 58 percent of businesses felt the impact of the epidemic on business operations was significantly negative, together, a total of 94 percent of them perceived some degree of adverse effect. Thus, by April, the epidemic affected all sectors of the Hungarian economy, of which tourism, entertainment and leisure activities were the biggest losers. The chemical industry, the trade in building materials, and legal, accounting, and administrative services, as well as architectural activities, were barely affected at first. This month, more than $30 \%$ of companies were prepared for forced leave, one-seventh for layoffs. Companies have responded primarily with (temporary) redundancies, unpaid leave, reductions in working hours, compulsory leave, or renegotiated wages, thus trying to survive the crisis. The sensitivity of the labour market is well illustrated by the fact that $99 \%$ of domestic enterprises are micro, small, or medium-sized enterprises (SMEs) that do not have multi-year reserves. Labour market responses have not only developed in this way in Hungary, but similar solutions have been reported in the USA, for example (Alon et al., 2020).

A repeated survey of Economic Research Co. (GKI) at the end of September 2020 shows the changes that have taken place in the meantime. In the distribution of forms of employment, the proportion of people who go to work full-time is by far the highest, at about 89 percent. There was no significant change in the share of part-time employees, their share was 6-7 percent in September. The proportion of teleworkers (from home) has remained low despite the recent intensification of the coronavirus epidemic. The main reason for this is certainly that there was no curfew in September. The proportion of those on leave, paid or unpaid leave, fell to 2 per cent. It may also mean that they have returned to a normal job (even part-time) or that they have been laid off (GKI, 2020b).

Compared to the EU economic prosperity index, the Hungarian data are less optimistic. While the EU index has covered about $60 \%$ of the fall due to the epidemic by August since the fall in April, the Hungarian economic prosperity index has only narrowed half of it, and the process of recovery has already been interrupted in August. At the same time, although the European economic outlook is picking up, overall, it is still gloomy and is unlikely to improve in September as the epidemic recovers (Eurostat, 2020).

The number of people affected by collective redundancies peaked in June like on global workplaces (Bacon \& Leia, 2020). From April to the end of July 2020, a total of almost a hundred employers announced collective redundancies involving more than 7,000 employees. The redundancies initially affected the hotel services, restaurant (Kashif et al., 2020), mobile and other hospitality, passenger transport, as well as the manufacture of electrical equipment and appliances, metalworking sectors, and later also accounting, auditing and tax expert activities.

Industry performance bottomed out in April 2020, when it fell nearly 45 percentage points in a month. In the same month, the turnover of retail stores also produced 
an average decrease of 16 percentage points, with the decline in non-food and fuel retail sales being particularly significant. In this area, it mainly affected retail companies with only a physical store network, as the restrictions shifted the focus of commerce to the online space and made many sales, trading, and treasury jobs redundant (Poór \& et al., 2020; Kim, 2020). However, the biggest losers were commercial accommodation. These represented a 99\% decrease in guest nights and a 97\% decrease in revenue in April 2020. Although government wages and other subsidies in Hungary mitigated the effects of the epidemic, they could not be fully neutralized (Csehné, 20219:

The decline is clearly explained by the epidemic situation. This is because the actual values are significantly lower than the estimates calculated from the time series data. In terms of individual sectors, employment in hospitality decreased the most: here it is estimated that the epidemic may have contributed to the loss of jobs of 22,600 people. In the much larger service sector 26,000 fewer people were employed, however, industrial employment barely changed, with the smallest decline in construction. Although agriculture was not directly affected by the epidemic, employment here also fell by 5,500 people. The above headcount figures do not represent a complete decrease, only new jobseekers registered by the National Employment Service (NFSZ). The changes in the industrial sector can be attributed almost entirely to the epidemic effect, while in hospitality, for example, the effect of seasonality must also be considered. These data and the conclusions that can be drawn from them paint a similar picture to the results of the HR research cited above, in which hospitality also proved to be the most affected sector. Restaurants and eateries that were able to switch to home delivery survived the first round of the crisis and were thus given a delay in finding a solution to their problems (Kim \& Lee, 2020).

The number of people affected by collective redundancies may increase at a later stage if new businesses are forced to lay off due to losses already realized or if the epidemic situation worsens, or if they can no longer survive a protracted crisis. This is also shown by the fact that already in the first phase of the epidemic, $45 \%$ of the organizations implementing redundancies stated that they had also implemented job terminations. At the same time, job or headcount expansion occurred in far fewer areas, most of which were IT (Kwan, 2020; Lesi, 2020) and logistics jobs related to e-commerce like worldwide (Pantelimon et al., 2020; Shahzad et al., 2020). In total, therefore, the creation of a new job for six terminations of jobs, or one increase of number of employees for five redundancies. In terms of proportions, therefore, far more people lost their jobs than those who found a new job as potential employees.

The decline in consumption and the generated inflation (Cavallo, 2020; Shapiro, 2020) due to COVID-19 infection primarily affected sectors that required physical interaction. This reduction in spending has greatly reduced the revenues of businesses that personally serve high-income households, especially of the one of small businesses. These businesses laid off most of their employees, causing a jump in unemployment. The reopening of the economy also had little effect on this. Incentive payments to low-income households have boosted consumption strongly but have had a modest impact on employment in the short run, perhaps because expenditures did not flow to the enterprises most affected by the COVID-19 shock - the experience is similar not only in Hungary but also abroad (Chetty et al., 2020).

The importance of human capital is also indicated by data, filtered by education (Gillies, 2015). In terms of the education of employees, the number of graduates who lost their jobs is still significantly lower than the number of those with lower education, and they have also been affected by job losses. At the same time, it is also clear that the downsizing was significant among those with primary education, vocational 
school, and high school graduates, and for those with up to 8 general education graduates, the cyclical nature of public employment may also play a role in the data. In the case of the latter two groups in particular, the increase in the number of people losing their jobs is striking, given that this was not the case for the same period in previous years. Poór et al. (2020) report results are also similar.

According to their survey, $94 \%$ of the redundancies affected the area of physical and mental trained work, while only a negligible number appear in managerial and decision-making positions. Most of those who lose their jobs are not only low-skilled but also low-paid. This further increases the burden on otherwise low-income families - a correlation that can be demonstrated in almost any part of the world (Chetty et al., 2020). The competencies that were reported to have appreciated in the first phase of the viral situation (digital competencies, problem-solving skills, leadership skills) are in some way related to higher education.

Given that COVID-19 is expected to radically change previous values and opinions, the authors of the present work add two comments to this issue. One is that even the current epidemic is not over and there may be another, similar problem at any time, so the rearrangement of the importance of competencies will almost certainly be a lasting change. Related to this is the second idea: using experience, we need to start developing these skills in education now, because education is a long-term process. Therefore, what is lacking now will not have an impact tomorrow, but decades from now, resulting in an important backlog for those now procrastinating.

\section{Material and methods}

We examine the changes in the labour market and the development of employment from three perspectives. We look at total employment and its two sub-areas separately, employment (employee relationship) and self-employment. This breakdown is because, as mentioned above, $99 \%$ of Hungarian enterprises are SMEs, which underlines the importance of self-employment. The goal we set for our research was to successfully identify how employment rates related to 11 items of Nomenclature of Economic Activities - NACE turned out between 2017 and 2019, as well as to identify how these tendencies became different in Hungary, by using the 27 member states of the EU as a benchmark for contrast for the first two quarters of 2020.

The database that served as the basis for comparison boasts quarterly time series concerning the European Union's entirety (excluding the UK because of Brexit). These time series were available based on four types of methodology:

- Raw data (without cleansing seasonality and calendar effects)

- Time series cleansed of seasonality,

- Time series cleansed of calendar effects,

- Time series cleansed of seasonality and calendar effects.

To ensure better comparability, we worked with times series cleansed to a high degree so that data, cleansed of seasonality and calendar effects, made up the database for our examination.

We examined the number of employed in three contexts:

- Total employment

- Employees

- Self-employed

It is important to note that the self-employed are mostly entrepreneurs. However, we cannot include individuals employed by small businesses as they belong to the employee category. 
We examined three hypotheses:

- H1 The total number of employed decreased as a result of the pandemic.

- H2 The primary victims of this decrease are employees.

- H3 The self-employed group (mostly entrepreneurs) was affected to

a lesser extent by the pandemic's effects on the labour market.

For our third hypothesis, we presumed that the effects of COVID-19 became mellower by two factors: the fact that individuals shifted from employees to being self-employed and that the smaller size of smaller businesses offered them the flexibility that made it easier for them to adapt to the situation.

Concerning the number of employees, we are talking about two units that completely differ geographically, so instead of measuring changes in an absolute way; we decided to measure them relatively. Accordingly, we placed an exponential trend function on quarterly data points between 2017 and 2019; then, we analysed the created models' slope coefficient in the same way as the relative change of 12 quarterly years. Note that there was only a single explanatory variable (trend) in all regression models, so the models' global test function's statistical significance corresponds to the explanatory variable's partial test function's statistical significance.

\section{Results and discussion}

\section{Results of incorporated models}

We can see the results of the incorporated models in Table 1 and Table 2 . The models almost all show significant changes in the examined period, and their explanatory power is also outstanding, mostly above $80-90 \%$. This high explanatory percentage is typical of EU-27 models - primarily because of predictability and stable change - , and there were only three exceptions: the number of employees in agriculture-forestry-fishing, construction, and the financial-insurance business among those who are self-employed. Here the explanatory power of models is below $30 \%$, and there was no significant change from one quarter to the next.

Out of the models fitted on the Hungarian data, we have not found a significant correlation in three cases. Regarding the areas of finance and insurance, the fitted model of 2017-2019 failed to demonstrate any significant quarter-to-quarter alterations during the twelve examined quarters either in the case of total employment or in the case of employees. Furthermore, not even the number of self-employed working in agriculture, forestry, and fishing industries deviated significantly from the constant value throughout the period considered.

\section{Total - All NACE activities together}

Considering all NACE activities, in the case of all employed individuals and employees we found similar differences between EU-27 and Hungary: In the previous three years before the virus, a $0.3-0.4 \%$ increase was typical which turned into a negative change of a similar magnitude in the first quarter of 2020 which was followed by a significant decrease in the second quarter. While the total number of employed individuals during the 2017-2019 period did not significantly deviate from the EU average, by the first quarter of 2020 the gap was beginning to widen which increased by the second quarter: Concerning the number of total employed individuals and employees, a less than 3\% decrease was observed in the EU while this same figure was 5.5\% in Hungary. The number of self-employed in Hungary during the twelve-quarter-long examination 
period increased by about $1.5 \%$ (in the EU this number decreased by a small amount), and this increase barely eroded by the first quarter of 2020 . In contrast a $0.42 \%$ decrease was observed in the EU which turned into a $1 \%$ decrease by the second quarter of 2020 , which barely deviated from the $-1.36 \%$ average of the EU - see Chart 1 .

Chart 1: Employment trends - economy

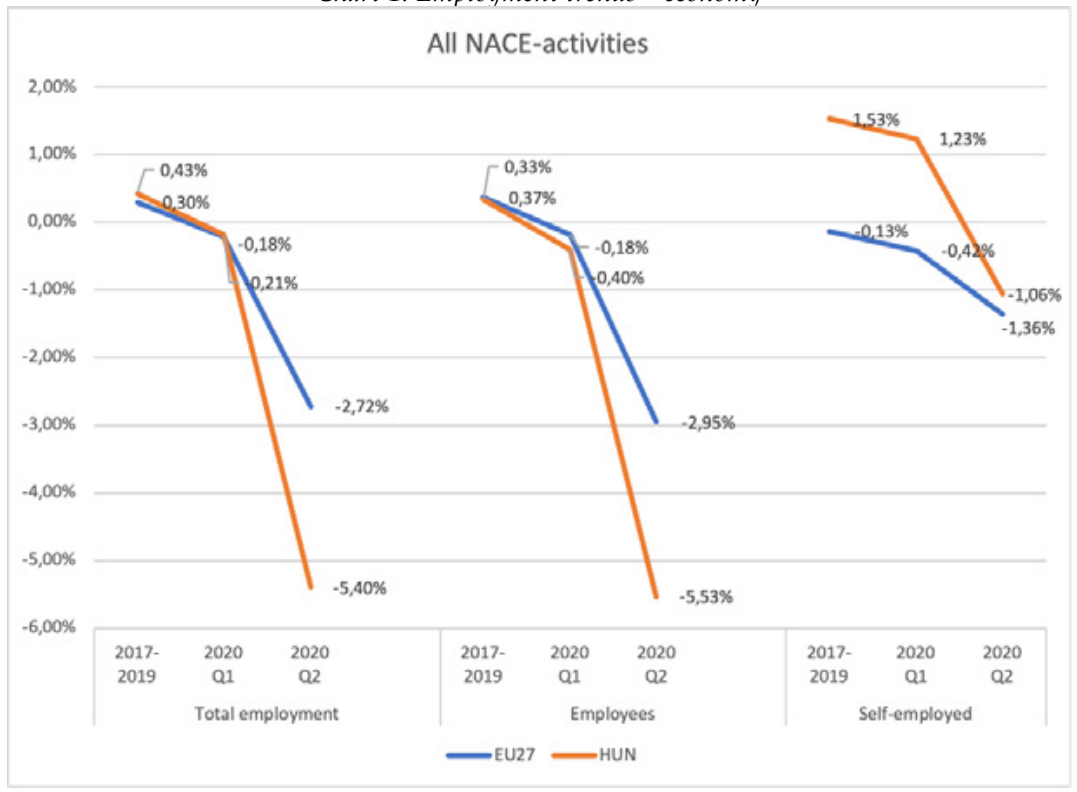

Source: Authors' own elaboration 
Table 1: Trends of employment data before and after the outbreak of COVID-19 in the EU

\begin{tabular}{|c|c|c|c|c|c|c|c|c|c|c|c|c|c|c|c|c|c|c|}
\hline \multirow{2}{*}{ EU27 } & \multirow[b]{2}{*}{$2017-2019$} & \multicolumn{5}{|c|}{ Total employment } & \multicolumn{6}{|c|}{ Employees } & \multicolumn{6}{|c|}{ Self-employed } \\
\hline & & $\begin{array}{c}2020 \\
\text { Q1 }\end{array}$ & $\begin{array}{l}2020 \\
\text { Q2 }\end{array}$ & $\mathrm{R}^{2}$ & $\mathrm{~F}(1 ; 10)$ & Sig. & 2017-2019 & $\begin{array}{c}2020 \\
\text { Q1 }\end{array}$ & $\begin{array}{l}2020 \\
\mathrm{Q} 2\end{array}$ & $\mathrm{R}^{2}$ & $F(1 ; 10)$ & Sig. & 2017-2019 & $\begin{array}{l}2020 \\
\text { Q1 }\end{array}$ & $\begin{array}{l}2020 \\
\mathrm{Q} 2\end{array}$ & $\mathrm{R}^{2}$ & $\mathrm{~F}(1 ; 10)$ & Sig. \\
\hline Total & $0.30 \%$ & $-0.21 \%$ & $-2.72 \%$ & 0.9748 & 386.44 & $<0.001$ & $0.37 \%$ & $-0.18 \%$ & $-2.95 \%$ & 0.9821 & 548.17 & $<0.001$ & $-0.13 \%$ & $-0.42 \%$ & $-1.36 \%$ & 0.7767 & 34.79 & $<0.001$ \\
\hline Agric, f\&f. & $-0.61 \%$ & $-1.58 \%$ & $-261 \%$ & 0.9207 & 116.14 & $<0.001$ & $0.08 \%$ & $-1.66 \%$ & $-2.34 \%$ & 0.2945 & 4.17 & 0.068 & $-0.95 \%$ & $-1.53 \%$ & $-2.75 \%$ & 0.9191 & 113.62 & $<0.001$ \\
\hline Idustry & $0.23 \%$ & $-0.42 \%$ & $-1.80 \%$ & 0.7946 & 38.69 & $<0.001$ & $0.26 \%$ & $-0.52 \%$ & $-1.85 \%$ & 0.8414 & 53.07 & $<0.001$ & $-0.42 \%$ & $1.45 \%$ & $-0.92 \%$ & 0.8310 & 49.19 & $<0.001$ \\
\hline Manufact. & $0.19 \%$ & $-0.50 \%$ & $-1.79 \%$ & 0.6236 & 16.57 & 0.002 & $0.23 \%$ & $-0.59 \%$ & $-1.83 \%$ & 0.7052 & 23.92 & 0.001 & $-0.45 \%$ & $1.01 \%$ & $-1.23 \%$ & 0.8387 & 51.99 & $<0.001$ \\
\hline Construct. & $0.64 \%$ & $0.48 \%$ & $-1.40 \%$ & 0.9846 & 641.02 & $<0.001$ & $0.80 \%$ & $0.71 \%$ & $-1.95 \%$ & 0.9894 & 930.20 & $<0.001$ & $0.09 \%$ & $-0.31 \%$ & $0.55 \%$ & 0.2580 & 3.48 & 0.092 \\
\hline Wholesale & $0.31 \%$ & $-0.65 \%$ & $-5.12 \%$ & 0.9774 & 432.08 & $<0.001$ & $0.42 \%$ & $-0.61 \%$ & $-5.42 \%$ & 0.9803 & 497.76 & $<0.001$ & $-0.27 \%$ & $-0.88 \%$ & $-3.42 \%$ & 0.8126 & 43.36 & $<0.001$ \\
\hline IT-comm. & $0.90 \%$ & $0.85 \%$ & $-1.18 \%$ & 0.9738 & 372.29 & $<0.001$ & $0.94 \%$ & $0.24 \%$ & $-1.22 \%$ & 0.9854 & 676.72 & $<0.001$ & $0.58 \%$ & $5.88 \%$ & $-0.87 \%$ & 0.4783 & 9.17 & 0.013 \\
\hline Finc. ins. & $-0.14 \%$ & $0.73 \%$ & $-262 \%$ & 0.8784 & 72.26 & $<0.001$ & $-0.17 \%$ & $0.83 \%$ & $-2.48 \%$ & 0.9161 & 109.16 & $<0.001$ & $0.10 \%$ & $-0.23 \%$ & $-3.88 \%$ & 0.1247 & 1.43 & 0.260 \\
\hline Real est. & $0.44 \%$ & $-0.46 \%$ & $-205 \%$ & 0.9373 & 149.40 & $<0.001$ & $0.39 \%$ & $-1.37 \%$ & $-2.32 \%$ & 0.9151 & 107.76 & $<0.001$ & $0.64 \%$ & $3.21 \%$ & $-1.02 \%$ & 0.8345 & 50.42 & $<0.001$ \\
\hline Prof., sci. & $0.48 \%$ & $-0.10 \%$ & $-3.82 \%$ & 0.9261 & 125.35 & $<0.001$ & $0.50 \%$ & $-0.02 \%$ & $-4.74 \%$ & 0.9217 & 117.76 & $<0.001$ & $0.37 \%$ & $-0.42 \%$ & $0.17 \%$ & 0.8822 & 74.91 & $<0.001$ \\
\hline Adm., def & $0.30 \%$ & $0.26 \%$ & $-0.43 \%$ & 0.9940 & 1643.2 & $<0.001$ & $0.28 \%$ & $0.28 \%$ & $-0.49 \%$ & 0.9937 & 1565.3 & $<0.001$ & $0.57 \%$ & $-0.03 \%$ & $0.56 \%$ & 0.9772 & 429.12 & $<0.001$ \\
\hline Art ent sve & $0.24 \%$ & $-0.52 \%$ & $-4.51 \%$ & 0.8938 & 84.19 & $<0.001$ & $0.21 \%$ & $-0.54 \%$ & $-5.74 \%$ & 0.8137 & 43.68 & $<0.001$ & $0.38 \%$ & $-0.41 \%$ & $0.91 \%$ & 0.8968 & 86.94 & $<0.001$ \\
\hline
\end{tabular}

Table 2: Trends of employment data before and after the outbreak of COVID-19 in Hungary

\begin{tabular}{|c|c|c|c|c|c|c|c|c|c|c|c|c|c|c|c|c|c|c|}
\hline \multirow{2}{*}{ Hungary } & \multicolumn{6}{|c|}{ Total Employment } & \multicolumn{8}{|c|}{ Employees } & \multicolumn{4}{|c|}{ Self-employed } \\
\hline & $\begin{array}{l}2017- \\
2019\end{array}$ & $\begin{array}{c}2020 \\
\text { Q1 }\end{array}$ & $\begin{array}{c}2020 \\
\text { Q2 }\end{array}$ & $\mathrm{R}^{2}$ & $F(1 ; 10)$ & Sig. & $\begin{array}{l}2017- \\
2019\end{array}$ & $\begin{array}{c}2020 \\
\text { Q1 }\end{array}$ & $\begin{array}{c}2020 \\
\mathrm{Q} 2\end{array}$ & $\mathrm{R}^{2}$ & $\mathrm{~F}(1 ; 10)$ & Sig. & $\begin{array}{l}2017- \\
2019\end{array}$ & $\begin{array}{c}2020 \\
\mathrm{Q} 1\end{array}$ & $\begin{array}{c}2020 \\
\text { Q2 }\end{array}$ & $\mathrm{R}^{2}$ & $\mathrm{~F}(1 ; 10)$ & Sig. \\
\hline Total & $0.43 \%$ & $-0.18 \%$ & $-5.40 \%$ & 0.9433 & 166.35 & $<0.001$ & $0.33 \%$ & $-0.40 \%$ & $-5.53 \%$ & 0.8969 & 86.97 & $<0.001$ & $1.53 \%$ & $1.23 \%$ & $-1.06 \%$ & 0.9908 & 1072.24 & $<0.001$ \\
\hline Agric. fikf. & $-0.41 \%$ & $0.47 \%$ & $-1.25 \%$ & 0.7039 & 23.77 & 0.001 & $-0.32 \%$ & $0.35 \%$ & $-3.35 \%$ & 0.5071 & 10.29 & 0.009 & $-0.54 \%$ & $0.07 \%$ & $264 \%$ & 0.3092 & 4.48 & 0.060 \\
\hline Manufact. & $0.39 \%$ & $-1.19 \%$ & $-3.64 \%$ & 0.7374 & 28.08 & $<0.001$ & $0.36 \%$ & $-1.27 \%$ & $-3.50 \%$ & 0.6913 & 22.39 & 0.001 & $1.49 \%$ & $206 \%$ & $-6.73 \%$ & 0.9422 & 162.90 & $<0.001$ \\
\hline Construct. & $1.99 \%$ & $1.67 \%$ & $-1.57 \%$ & 0.9580 & 228.33 & $<0.001$ & $1.78 \%$ & $1.12 \%$ & $-1.77 \%$ & 0.9332 & 139.71 & $<0.001$ & $3.50 \%$ & $3.98 \%$ & $1.11 \%$ & 0.9779 & 441.74 & $<0.001$ \\
\hline Wholesale & $0.38 \%$ & $-0.15 \%$ & $-8.71 \%$ & 0.9185 & 112.75 & $<0.001$ & $0.42 \%$ & $-0.23 \%$ & $-8.76 \%$ & 0.9286 & 130.04 & $<0.001$ & $-0.28 \%$ & $1.05 \%$ & $-5.13 \%$ & 0.5611 & 12.79 & 0.005 \\
\hline Пт-comm. & $1.41 \%$ & $1.99 \%$ & $-2.38 \%$ & 0.9801 & 493.08 & $<0.001$ & $0.96 \%$ & $0.18 \%$ & $-1.63 \%$ & 0.9417 & 161.51 & $<0.001$ & $5.42 \%$ & $2.37 \%$ & $-1.72 \%$ & 0.9898 & 968.76 & $<0.001$ \\
\hline Finc. ins. & $-0.12 \%$ & $1.09 \%$ & $-1.66 \%$ & 0.0292 & 0.30 & 0.596 & $-0.26 \%$ & $0.33 \%$ & $-1.10 \%$ & 0.1624 & 1.94 & 0.194 & $1.24 \%$ & $-3.19 \%$ & $-3.74 \%$ & 0.9061 & 96.44 & $<0.001$ \\
\hline Artent svc & $1.30 \%$ & $-3.65 \%$ & $-4.33 \%$ & 0.9113 & 102.78 & $<0.001$ & $0.75 \%$ & $-4.94 \%$ & $-7.07 \%$ & 0.8363 & 51.09 & $<0.001$ & $3.17 \%$ & $-1.21 \%$ & $-1.30 \%$ & 0.9740 & 374.13 & $<0.001$ \\
\hline
\end{tabular}

Source: Authors' own elaboration 
We analysed all the economic activities with similar procedure; therefore, we do not particularize it in thorough details due to the limit of word count. Nevertheless, the most important results are delineated in the chapter 'Conclusion'.

\section{Conclusion}

In summary, we can argue that the pandemic has triggered very harmful processes for employees in all sectors, reducing the number of employed individuals, i.e., we proved our first hypothesis. Table 3 summarises our findings.

Table 3: Effects of COVID-19 on NACE activities

\begin{tabular}{|c|c|c|c|c|c|c|c|}
\hline \multirow{3}{*}{$\begin{array}{l}\text { No. } \\
1 .\end{array}$} & \multirow{3}{*}{$\begin{array}{l}\text { NACE activities } \\
\text { Agriculture, forestry, and fishing }\end{array}$} & \multicolumn{6}{|c|}{ 2017-2019-2020Q1 - 2020Q2 } \\
\hline & & \multicolumn{3}{|c|}{ Hungary } & \multicolumn{3}{|c|}{ EU-27 } \\
\hline & & & $\pi$ & y & y & y & $\hat{\imath}$ \\
\hline 2. & Industry (except construction) & $\pi$ & $\mathbf{y}$ & $\hat{\imath}$ & $\pi$ & y & $\hat{\imath}$ \\
\hline 3. & Manufacturing & $\pi$ & $\mathbf{y}$ & y & $\pi$ & ע & y \\
\hline 4. & Construction & $\lambda$ & $\pi$ & $\hat{\imath}$ & $\pi$ & $\pi$ & $\hat{\imath}$ \\
\hline 5. & $\begin{array}{l}\text { Wholesale and retail trade, transport, accommodation, } \\
\text { and food service activities }\end{array}$ & & $\mathbf{y}$ & $\hat{\imath}$ & $\pi$ & y & y \\
\hline 6. & Information and communication & $\pi$ & $\pi$ & y & $\pi$ & $\pi$ & y \\
\hline 7. & Financial and insurance activities & & $\pi$ & $\hat{\imath}$ & y & $\pi$ & $\hat{\imath}$ \\
\hline 8. & Real estate activities & & $\lambda$ & $\hat{\imath}$ & $\pi$ & y & $\hat{\imath}$ \\
\hline 9. & $\begin{array}{l}\text { Professional, scientific, and technical activities; administrative } \\
\text { and support service activities }\end{array}$ & & $\lambda$ & $\hat{\imath}$ & $\pi$ & ע & y \\
\hline 10. & $\begin{array}{l}\text { Public administration, defence, education, human health, } \\
\text { and social work activities }\end{array}$ & & $y$ & $\hat{1}$ & $\pi$ & 入 & y \\
\hline 11. & $\begin{array}{l}\text { Arts, entertainment, and recreation; other service activities; } \\
\text { activities of household and extra-territorial organizations and bodies }\end{array}$ & & s & $\hat{1}$ & $\pi$ & ע & $\hat{\imath}$ \\
\hline
\end{tabular}

Source: Authors' own elaboration

(Notes: $\boldsymbol{\lambda}$ means increasing, $\boldsymbol{y}$ means decreasing)

There were areas more severely affected (e.g., trade; professional, scientific, and technical activities) and also those where it caused only a 1-2\% decrease (e.g., construction, information, and communication). As the number of self-employed is relatively low, the development of the number of employed individuals showed great similarity in almost all sectors compared to the total number of employed individuals. For the same reason, it was also the stratum of workers most affected by the effects of the epidemic. So, we also proved our second hypothesis. Although the number of self-employed fell sharply in some sectors, Hungary was more exposed to hectic changes (e.g., industry, excluding construction, the real estate sector; public administration, defence, education, human health, and social work). However, there have been several instances where growth has only moderated or barely changed (e.g., construction; professional, scientific, and technical activities; arts, entertainment, and other service activities). but the strong Hungarian agricultural sector compared to other countries showed a really strong strengthening in the second quarter of the pandemic. The third hypothesis was thus partially confirmed in certain sectors of the economy. Hungary has successfully overcome the first wave of the epidemic and is consciously (Görgény-Hegyes et al., 
2021) paring to defend itself against the second wave, which is still ongoing. According to the data of the National Employment Service at the end of October 2020, the number of jobseekers has been declining for the nineteenth week, currently 306 thousand people. Meanwhile, the unemployment rate was only 0.9 percentage points higher than in the same period last year. These data are also favourable in the EU comparison, Hungary ranks 3rd among the EU-27 countries. One of our further goals is to enlarge the scope of data, e.g., with the focus on V4 countries. Our objective is to overview and analyse the field of human capital in a wider perspective, in particular, the concepts articulated by Industry 4.0 .

\section{Bibliography}

1. Adeel, A. B., Catalano, M., Catalano, O., Gibson, G., Muftuoglu, E., Riggs, T., Sezgin, M. H., Shvetsova, O., Tahir, N., VanDusky-Allen, J., Zhao, T., \& Zhirnov, A. (2020). COVID-19 Policy Response and the Rise of the Sub-National Governments. Canadian Public Policy, 46(4). 565-584 https://doi.org/10.3138/cpp.2020-101

2. Alon, T., Doepke, M., Olmstead-Rumsey, J., \& Tertilt, M. (2020). The Impact of COVID-19 on Gender Equality. Working Paper 26947. National Bureau of Economic Research. https://doi.org/10.3386/w26947

3. Bacon, C., \& Leia, O. (2020). Covid-19 and the Global Workplace. International Newsletter, 2(2), 8-12. Retrieved from: https://www.velaw.com/insights/covid-19and-the-global-workplace/ on March 26, 2021.

4. Bakó T. \& Lakatos J. (2020). Hungarian labour market 2019-2020. (In Hungarian) Retrieved from https://kti.krtk.hu/wp-content/uploads/2020/12/mt_2019_mo_ mp_2019_20.pdf on July 16, 2021.

5. Balogh G., Király Z., Kópházi A., Kun A. I., \& Poór J. (2020). Objectives, Methods, and First Experiences of the Hungarian National Research Project "KoronaHR", ( in Hungarian). New Hungarian Labour Review (Uj Munkaügyi Szemle), (4), 2-7. Retrieved from: https://www.metropolitan.hu/upload/ f2d5952177683d16d08cad43e93bd7049d1aa133.pdf on April 10, 2021.

6. Caligiuri, P., De Cieri, H., Minbaeva, D., Verbeke, A., \& Zimmermann, A. (2020). International HRM insights for navigating the COVID-19 pandemic: Implications for future research and practice. Journal of International Business Studies, 51(5), 697713. https://doi.org/10.1057/s41267-020-00335-9

7. Carnevale, J. B., \& Hatak, I. (2020). Employee adjustment and well-being in the era of COVID-19: Implications for human resource management. Journal of Business Research, 116, 183-187. https://doi.org/10.1016/j.jbusres.2020.05.037

8. Cavallo, A. (2020). Inflation with Covid Consumption Baskets. Working Paper 20-124. Retrieved from: https://ssrn.com/abstract=3622512 on April 3, 2021.

9. Chetty, R., Friedman, J. N., Hendren, N., \& Stepner, M. (2020). How Did COVID-19 and Stabilization Policies Affect Spending and Employment? A New Real-Time Economic Tracker Based on Private Sector Data. Working Paper 27431. National Bureau of Economic Research. Retrieved from: https://www.nber.org/system/files/ working_papers/w27431/w27431.pdf on March 23, 2021.

10. Chulanova , K. Z. (2017). The Human Capital as a Factor of Competitiveness and Economic Development. East Asian Journal of Business Management, 7(3), 23-31

11. Csehné P.I. (2021). Different aspects of crisis. (In Hungarian) New Hungarian Labour Review (Uj Munkaügy Szemle), 2(1), 24-30.1)

12. Douglass, J. A. (2010). Creating a Culture of Aspiration: Higher Education, Human Capital and Social Change | Elsevier Enhanced Reader. Procedia - Social and 
Behavioral Sciences, 2(5), 6981-6995. https://doi.org/10.1016/j.sbspro.2010.05.050

13. Dzhurova, A. (2020). Symbolic politics and government response to a national emergency: Narrating the COVID-19 crisis. Administrative Theory \& Praxis, 42(1), 1-17. https://doi.org/10.1080/10841806.2020.1816787

14. Eurostat. (2020). Eurostat Labour Market Report. Retrieved from: https://ec.europa. eu/eurostat/statistics-explained/index.php?title=Employment_rates_\%E2\%80\%93 annual statistics on April 8, 2021.

15. Ezzul Esa, M., Mahzan Awang, M., Razaq Ahmad, A., \& Ahmad, A. (2019). Developing Thinking Skills Among Students Towards Creating Quality Human Capital. Proceedings of The 2nd International Conference on Sustainable Development \& Multi-Ethnic Society - Icosh2 2019, 208-215. https://doi.org/10.32698/GCS.0199

16. Fogel, R. W. (1994). Economic Growth, Population Theory, and Physiology: The Bearing of Long-Term Processes on the Making of Economic Policy. The American Economic Review, 84(3), 369-395. https://doi.org/10.3386/w4638

17. Gillies, D. (2015). Human Capital Theory in Education. In: Peters, M. (Ed.) Encyclopedia of educational philosophy and theory. Singapore: Springer. https://doi. org/10.1007/978-981-287-532-7_254-1

18. GKI. (2020a). In April GKI's Economic Sentiment Index has plummeted to an unprecedented degree (In Hungarian). GKI. Retrieved from: https:/www.gki.hu/ wp-content/uploads/2020/04/GKI-fogyaszt\%C3\%B3i-bizalmi-index-200409.pdf on April 2, 2021

19. GKI. (2020b). It Is the Second Month that the Economic Sentiment Index of GKI Economic Research Co. could not have increased (In Hungarian). Retrieved from: https://www.gki.hu/wp-content/uploads/2020/09/GKI_konj_2009.pdf on April 25, 2021

20. Gorgenyi-Hegyes E, Nathan RJ. \& Fekete-Farkas M. (2021). Workplace Health Promotion, Employee Wellbeing and Loyalty during Covid-19 Pandemic - Large Scale Empirical Evidence from Hungary. Economies, 9(2):55. https://doi. org/10.3390/economies 9020055

21. Hsieh, C.-T., \& Klenow, P. J. (2010). Development Accounting. American Economic Journal: Macroeconomics, 2(1), 207-223. https://doi.org/10.1257/mac.2.1.207

22. Kashif, M., Rehman, A.-U., \& Javed, K. (2020). Demystify the Covid-19 Effect on Restaurant. International Journal of Medical Science in Clinical Research and Review, 3(3). Retrieved from: http://www.ijmscrr.in/index.php/ijmscrr/article/ Q view/85/63 on February 25, 2021.

23. Kim, J., \& Lee, J. C. (2020). Effects of COVID-19 on preferences for private dining facilities in restaurants. Journal of Hospitality and Tourism Management, 45(12), 67-70. https://doi.org/10.1016/j.jhtm.2020.07.008

24. Kim, R. Y. (2020). The Impact of COVID-19 on Consumers: Preparing for Digital Sales - IEEE Journals \& Magazine. IEEE Engineering Management Review, 48(3), 212-218. https://doi.org/10.1109/EMR.2020.2990115

25. Kiseláková, D., Sirá, E. \& Sofranková, B. (2018). The performance of V4 countries according to ease of doing business index. Acta Oeconomica Universitatis Selye, 9 (2), 71-80. Retrieved from: http://acta.ujs.sk/docs/Acta\%207_2\%20print.pdf on April 20, 2021.

26. KSH. (2020). STADAT - 2.1.7.2. (2008-2019). Retrieved from: https://www.ksh.hu/ docs/hun/xstadat/xstadat_eves/i_qlf005a.html on March 22, 2021.

27. Kwan, S. H., \& Mertens, T. M. (2020). Market Assessment of COVID-19. FRBSF Economic Letter, 2020(14), 1-5. Retrieved from: https://www.frbsf.org/ 
economic-research/publications/economic-letter/2020/may/marketassessment-of-covid-19/ on January 28, 2021.

28. Lesi, H. (2020). The Influence of Information Technology Covid-19 Plague Against Financial Statements and Business Practices. Ilomata International Journal of Tax \& Accounting, 1(3), 10. https://doi.org/10.52728/ijtc.v1i3.117

29. Pantelimon, F.-V., Georgescu, T. M., \& Posedaru, B.-S. (2020). The Impact of Mobile e-Commerce on GDP: A Comparative Analysis between Romania and Germany and how Covid-19 Influences the e-Commerce Activity Worldwide. Informatica Economica, 24(2/2020), 27-41. https://doi.org/10.24818/ issn14531305/24.2.2020.03

30. Pasban, M., \& Nojedeh, S. H. (2016). A Review of the Role of Human Capital in the Organization. 5. http://doi.org/10.1016/j.sbspro.2016.09.032

31. Poór, J., Balogh, G., Dajnoki K., Karoliny, M., Kun, A. I. [Eds.]. (2020). Coronavirus Crisis. Challenges and HR Responses. Hungary 2020 (Assessment of the first research phase), in Hungarian]. Szent István University. Management and HR Research Centre. Retrieved from: https://mkik.hu/ckfinder/files/KoronaHR kutata $\%$ CC $\% 81$ si-jelente $\%$ CC $\% 81$ s.pdf on April 3, 2021

32. Samans, R., Zaidi, S., Leopold, T. A., \& Ratcheva, V. (2017). The Global Human Capital Report 2017. World Economic Forum. Retrieved from: https://weforum.ent. box.com/s/dari4dktg4jt2g9xo2o5pksjpatvawdb on April 14, 2021

33. Schultz, T. W. (1961). Investment in human capital. The American Economic Review, 51(1), 1-17. Retrieved from: https://www.jstor.org/stable/1818907 on March 10, 2021.

34. Schultz, T. W. (1980). The Economics of Being Poor. Bulletin of the Atomic Scientists, 36(9), 32-37. https://doi.org/10.1080/00963402.1980.11458781

35. Shahzad, A., Hassan, R., Abdullah, N. I., Hussain, A., \& Fareed, M. (2020). Covid-19 Impact on E-Commerce Usage: An Empirical Evidence from Malaysian Healthcare Industry. Humanities \& Social Sciences Reviews, 8(3), 599-609. https://doi.org/10.18510/hssr.2020.8364

36. Shapiro, A. H. (2020). A Simple Framework to Monitor Inflation. Federal Reserve Bank of San Francisco Working Paper Series 2020-29. https://doi.org/10.24148/ wp2020-29

37. Smith, A. (1776). An Inquiry into the Nature and Causes of the Wealth of Nations. London: W. Strahan, \& T.Cadell.

38. Szappanos, J. (2020Assessment of the Impact of the COVID-19 Pandemic on Public Finances, in Hungarian. EL-2555-020/2020. State Audit Office of Hungary. Retrieved from: https://www.asz.hu/storage/files/files/elemzesek/2020/ covid_20200629.pdf?download=true on March 5, 2021

39. Szellö J. (2020). Pandemic and the Global Workforce Market, (in Hungarian). New Hungarian Labour Review (Uj Munkaügyi Szemle), 1(4), 17-22. Retrieved from: https://www.metropolitan.hu/upload/387b1fc214e9514a34e7b2ea39157d 7b512ce538.pdf on February 28, 2021.

40. World Bank. (2020). The Human Capital Index 2020 Update: Human Capital in the Time of COVID-19. Washington, DC, USA: World Bank. Retrieved from: https://openknowledge.worldbank.org/handle/10986/34432 on February 28, 2021 


\section{Correspondence address:}

Arnold Tóth, PhD, Department of Business Economics, Faculty of Finance and Accountancy, Budapest Business School, 29-31 Markó utca, Budapest H-1055, Hungary, email: toth.arnold@uni-bge.hu

Botond Kálmán, MSc, Faculty of Law, Eötvös Loránd University, 1-3 Egyetem tér, Budapest H-1053, Hungary, email: kalmanbotond@student.elte.hu

Prof. Dr. József Poór, DSc, Department of Management, Faculty of Economics and Informatics at J. Selye University , Hradná str. 167/21, Komárno, Slovakia, e-mail: poorj@ ujs.sk 
Name of the publication: ACTA OECONOMICA UNIVERSITATIS SELYE International scientific journal

Editor - in - Chief:

\section{Ladislav Mura}

Authors:

C Ida ERCSEY - László JÓZSA - Zuzana HAJDUOVÁ - František SEBESTYÉN - Katarína HAVIERNIKOVÁ - Michal Hrivnák - Peter Moritz - Ĺubor JUSKO - Nikoleta HUTMANOVÁ - Ĺudovít MOLITORIS - Réka SZONDI - Éva GERGELY - Arnold TÓTH - Botond KÁLMÁN - József POÓR

Year: 2021

Volume 10.

No. 1

The Journal is published twice a year.

This issue was published in June 2021.

Publisher: J. Selye University, Faculty of Economics and Informatics, Bratislavská cesta 3322, 94501 Komárno, www.ujs.sk, IČO: 37961632

Prepared by: DMC, s.r.o.

ISSN 1338-6581, e-ISSN 2644-5212, EV 4538/12 MK SR

Price: 12,- EUR 